\title{
Lesní alternativa předškolního vzdělávání v České republice zachráněna
}

\section{Vendula Soběslavská}

Envigogika 10 (2) - Informace/Information

Publikováno/Published dne 26. 9. 2015

DOI: $\underline{10.14712 / 18023061.491}$

\begin{abstract}
Abstrakt
Asociace lesních mateřských škol $v$ České republice čítá již na sto dvacet předškolních vzdělávacích zařízení. Donedávna byla jejich existence ohrožena v souvislosti $s$ procesem schvalování Zákona o poskytování služby péče o dítě $v$ dětské skupině. Nejen formou petic, ale i aktivní účastí na tvorbě novely zákona se podařilo zajistit lesním mateřským školám místo na poli předškolního vzdělávání.
\end{abstract}

\section{Klíčová slova}

Lesní mateřské školy; certifikace kvality; zákonodárná úprava

\begin{abstract}
The Association of Forest Kindergartens in the Czech Republic now has a membership of 120 pre-school educational establishments. Until recently, their existence was threatened in connection with the approval process for the Law on the Provision of Childcare Services in Children's Groups. Recently the Association succeeded in securing a place for forest nursery schools in the early childhood education system - not only through petitions, but also through active participation in the discussion on the amended Act.
\end{abstract}

\section{Keywords}

Forest kindergarten; quality certification; legislation 
Lesní mateřské školy jako zařízení předškolního typu nejsou $v$ naší zemi žádným nováčkem. Mezi první lesní mateřské školy (LMŠ) na našem území patří Zelená školka Jítrava založená na Liberecku v roce 2007. O dvě léta později byl založen v Čechách v Šáreckém údolí dětský klub Šárynka a současně na Moravě dětský klub v Pejškově, nyní lesní rodinný klub na Tišnovsku. Inspirací těmto školkám byly lesní mateřské školy v Německu a Rakousku. Do roku 2012 bylo v České republice založeno více než padesát školek a od té doby se jejich počet opět značně zvýšil. $V$ dnešní době registruje Asociace lesních mateřských škol přes 120 organizací, vzdělávajících na 2500 dětí.

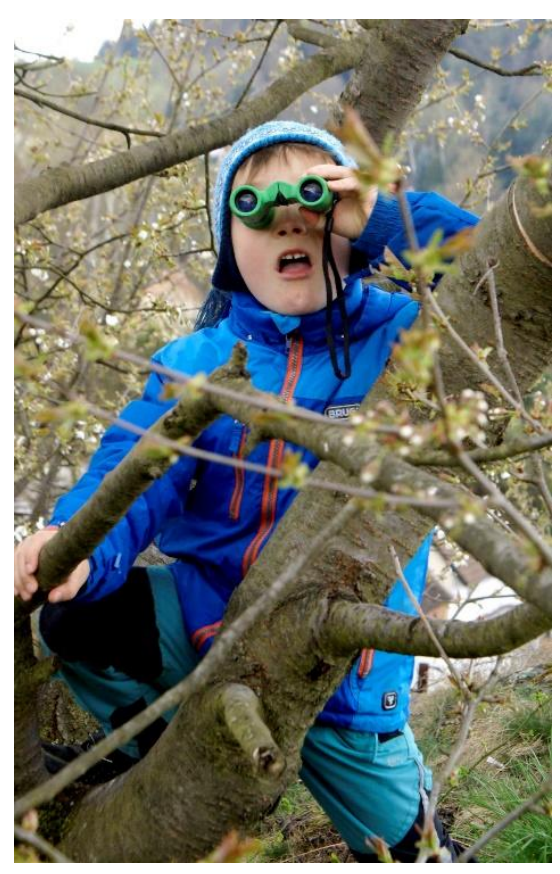

A právě Asociace lesních mateřských škol (ALMŠ), založená v roce 2011, v čele s předsedkyní Terezou Valkounovu, je zastřešující organizací pro téměř všechny lesní iniciativy u nás. ALMŠ $v$ rámci svých cílů poskytuje podporu a poradenství členům a subjektům zabývajícím se předškolním vzděláváním podle myšlenek lesních mateřských škol. Po celé ČR organizuje řadu vzdělávacích kurzů, seminářů či expedic, taktéž pořádá již tradičně několikadenní letní školu pro pedagogy LMŠ se zastoupením hostů ze zahraničí. České lesní mateřské školy mají díky práci ALMŠ jako jediné na světě možnost certifikace dle Standardü kvality LMŠ. Krom dalšího je posláním AMLŠ také vyjednávání $s$ orgány veřejné moci $v$ záležitostech vytváření a úpravy legislativy týkající se péče a vzdělávání dětí v LMŠ. Do hledáčků médií se lesní školky blíže dostaly během jarních měsíců v roce 2014 v souvislosti se schvalováním Zákona 247/2014 Sb., tedy Zákona o poskytování služby péče o dítě $\mathbf{v}$ dětské skupině, který byl nejprve přijat Poslaneckou sněmovnou v červnu 2014. Cílem zákona bylo rozšíření možnosti péče o dítě $v$ předškolním věku a také daňová podpora pro rodiče dětí $v$ těchto zařízeních $i$ pro provozovatele. $V$ reálném dopadu zákona se však nejednalo pouze o proklamované rozšíření péče, nýbrž o institucionální zarámování veškerých existujících subjektů. Toto původní znění zákona bylo pro všechny odlišné formy péče o malé děti, včetně lesních školek, likvidační. Zejména se jednalo o nesplnitelnost podmínek, např. parametrů vnitřních prostor, které LMŠ měly dle tohoto zákona mít srovnatelné s klasickými školkami, což není při provozu těchto zařízení, zaměřených na vzdělávací program $v$ prírodním prostředí, významné ani žádoucí.

Petici pro zachování lesních mateřských škol určenou pro Senát podepsalo v rozmezí tř́ týdnů na 13 tisíc lidí. Akce na záchranu lesních školek byla orientována také na oslovení konkrétních politických zástupců $v$ jednotlivých krajích. Zákon se poté podařilo vrátit do Poslanecké sněmovny a jako řešení vzniklé situace se začalo nabízet jednání o možnosti volitelnosti registrace $\mathrm{k}$ dětské skupině namísto povinné registrace a hrozby sankcí. Toto řešení nezamezuje vznikání dětských skupin, a přitom zaručuje možnost fungovat i bez zákonem nabízených výhod. 


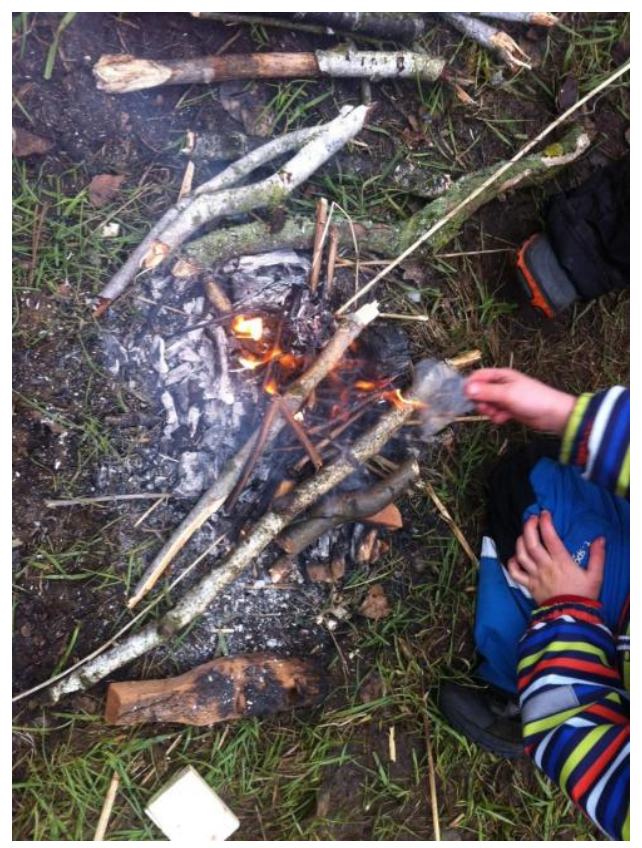

Navzdory dalšímu projednávání, mediální kampani a další petici s 15 tisíci podpisy přijala během podzimu Poslanecká sněmovna opakovaně - po přehlasování veta prezidenta nevyhovující zákon $v$ pưvodním znění $a$ v listopadu 2014 byl Parlamentem ČR zákon přijat. Zástupci LMŠ se tak spolu s dalšími provozovateli volnočasových aktivit pro předškolní děti (např. školky pro děti ve vyloučených lokalitách společnosti Člověk v tísni, předškolní skauti, rodinná centra) ocitli v nejistotě, zda budou moci od září 2015 fungovat. Toto spojenectví bylo pro další vyjednávání velmi důležité. Se schválením a přijetím zákona byla ale zároveň vyjádřena ze strany některých politických představitelů vůle vytvořit novelu zákona, která by zahrnovala volitelnost registrace do dětské skupiny. 0 vytvoření novely se svým aktivním přispěním zasadili jmenovitě senátorka Miluše Horská, poslanec Jiří Mihola a poslankyně Helena

Langšádlová. V květnu 2015 byla parlamentem schválena a prezidentem podepsána novela Zákona o poskytování péče o dítě v dětské skupině umožňující dobrovolnost registrace do Evidence dětských skupin. Tímto bylo ukončeno dlouhé období nejistoty ohledně existence lesních školek a v podstatě i všech dalších předškolních alternativ vybočujících z rámce dětské skupiny.

Děti, rodiče, pedagogové i př́znivci LMŠ tak mohou být spokojeni. Lesní mateřské školy jako alternativní péče předškolní výchovy a vzdělávání zůstávají zachovány. Budoucnost stávajících i nových lesních vzdělávacích iniciativ není ohrožena. Lesní školky získaly v uplynulém náročném období jistě mnoho odpưrců, ale na své straně mají dnes také celou řadu veřejně známých osobností kulturního i politického života. Ukázalo se, že síla hnutí lesních mateřských škol v ČR není ani zdaleka mizivá. Díky prošlápnuté cestě ve veřejném sektoru bude snad i každé další jednání o př́padném zařazování LMŠ do

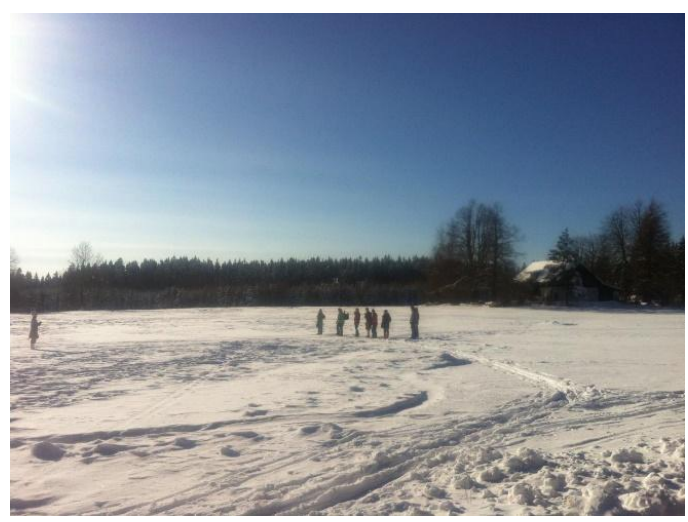
školského systému o kus snazší.

\section{Zdroje}

- $\quad$ Asociace lesních mateřských škol: http://lesnims.czl

- Standardy kvality LMŠ: http://lesnims.cz/standardy-kvality-Ims

- E-petice:

http://www.e-petice.cz/petitions/za-zmenu-zakona-o-detskych-skupinach-.html 